\section{Dinucleotide repeat polymorphism at the FTHPI locus of chromosome 6}

\author{
V.Mauvieux, A.M.Jouanolle, A. El Kahloun, M.Blayau, \\ J.Y. Le Gall and V.David \\ Laboratoire de Biochimie Médicale B, Faculté de \\ Médecine, 35043 Rennes Cédex, France
}

Source/Description: This $(\mathrm{CA})_{15}$ repeat was localized on the chromosome $6,2.3 \mathrm{~Kb}$ upstream of a $\mathrm{H}$-ferritin pseudogene (FTHPI). FTHPI was cloned as a $12 \mathrm{~Kb}$ HindIII fragment in lambda $\mathrm{L} 47-1$ phage and the interesting sequence subcloned as a $2.6 \mathrm{~Kb}$ EcoRV fragment in the Bluescript plasmid. (Accession name of sequence of FTHPI is HUMFERHX).

PCR Primers: Sequences flanking this repeat were used to design PCR primers:

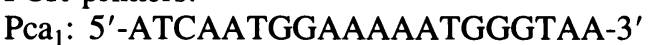

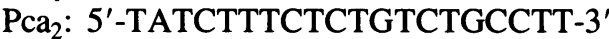

Polymorphism: Using 5' [ ${ }^{32} \mathrm{P}$ ] end labeled primer Pcal to label the GT containing strand, fragments of variable length were detected on DNA sequencing gels. Lengths of allelic fragments were determined relative to M13 sequence (Primer-40 USB). $A_{1}=181, A_{2}=179, A_{3}=177, A_{4}=175, A_{5}=173, A_{6}$ $=171 \mathrm{bp}$.

Frequencies: Allele frequencies from 21 unrelated European Caucasians: $\mathrm{A}_{1}=.048, \mathrm{~A}_{2}=.215, \mathrm{~A}_{3}=.215, \mathrm{~A}_{4}=.166, \mathrm{~A}_{5}$ $=.190, \mathrm{~A}_{6}=.166$.

$\begin{array}{lll}\text { Allele } & \mathrm{bp} & \text { Frequency } \\ \mathrm{K} 1 & 181 & 0.048 \\ \mathrm{~K} 2 & 179 & 0.215 \\ \mathrm{~K} 3 & 177 & 0.215 \\ \mathrm{~K} 4 & 175 & 0.166 \\ \text { K5 } & 173 & 0.190 \\ \text { K6 } & 171 & 0.166\end{array}$

Observed heterozygosity: $90.5 \%$.

Chromosomal Localization: The FTHPI locus was previously mapped to $6 \mathrm{p} 12-6 \mathrm{p} 21.3$ by in situ hybridization (1) and by a two point linkage analysis most closely linked to the MUT locus (2).

Probe and Sequence Availability: Contact V.David.

PCR Conditions: We carried out PCR in a total volume of 25 $\mu$ l containing: $50 \mathrm{ng}$ genomic DNA, 3.5 pmoles of each primer, $1.5 \mathrm{mM} \mathrm{MgCl}, 10 \mathrm{mM}$ Tris- $\mathrm{HCl} \mathrm{pH} 8.3,50 \mathrm{mM} \mathrm{KCl}$, $0.001 \%$ gelatine, $200 \mu \mathrm{M}$ dNTP and 1 unit Taq polymerase (Beckman).

Amplification was for 30 cycles with denaturation at $94^{\circ} \mathrm{C}$ for $1 \mathrm{~min}$, annealing at $48^{\circ} \mathrm{C}$ for $1 \mathrm{~min}$ and extension at $72^{\circ} \mathrm{C}$ for $30 \mathrm{sec}$.

Acknowledgements: This work was supported in part by INSERM (CRE no. 887013), Ministère de la Recherche et de la Technologie (No. 90.C.0404).

References: 1) MacGill et al. (1985) Cytogenet. Cell Genet. 40, 696-697. 2) Mauvieux et al. (1991) NAR 19, 5100.

\section{BstNI/Ncil polymorphism of the human p53 gene (TP53)}

P.M.Chumakov and J.R.Jenkins ${ }^{1}$

Engelhardt Institute of Molecular Biology, Academy of

Sciences of the USSR, 117984 Moscow, USSR and

${ }^{1}$ Marie Curie Research Institute, The Chart, Oxted, Surrey,

RH8 OTL, UK

We report a new sequence polymorphism within the 6th intron of the human p53 gene that can be revealed using restriction nuclease digestion of PCR-amplified DNA segment.

PCR Primers: Left-hand (sense) oligonucleotide 5'-GTTGCCCAGGGTCCCCAGGCCTCTGATTCCTCACT corresponded to the region of intron 512 bp upstream of exon 6; Right-hand (antisense) oligonucleotide 5'-GGGAGGCCCTTAGCCTCGTAAGCTTCA corresponded to the region of intron 6165 bp downstream of exon 6 (1).

Polymorphism: BstNI (CCAGG) and Ncil (CCGGG) cleave different allele fragments of the p53 gene: BstNI (K1): $206+$ $130 \mathrm{bp}$; NciI (K2): $221+130 \mathrm{bp}$.

Frequency: Allele frequencies were calculated from 56 unrelated Caucasians:

$\mathrm{K} 1=0.31$

$\mathrm{K} 2=0.69$

Chromosomal Localization: The polymorphic A/G nucleotide responsible for BstNI/NciI restriction site polymorphism is localized in intron $6,61 \mathrm{bp}$ downstream of exon 6 of the p53 gene (17p13) (2).

Mendelian Inheritance: Was demonstrated in two three-generation families.

PCR Conditions: PCR amplifications were carried out in a volume of $100 \mu$ l containing: $1 \mu \mathrm{g}$ of genomic DNA, 100 pmoles of primers, $100 \mu \mathrm{M}$ dNTP, $50 \mathrm{mM} \mathrm{KCl}, 20 \mathrm{mM}$ Tris. $\mathrm{HCl} \mathrm{pH}$ $8.3,0.1 \%$ gelatine for 35 cycles (annealing temperature $58^{\circ} \mathrm{C}$ ). The amplified fragment was purified by spermine precipitation, digested with BstNI or NciI restriction nucleases and subjected to electrophoresis through $2 \%$ agarose.

References: 1) Chumakov,P. et al. (1990) EMBL Data Library accession number X54156. 2) Miller et al. (1986) Nature 319 $783-784$

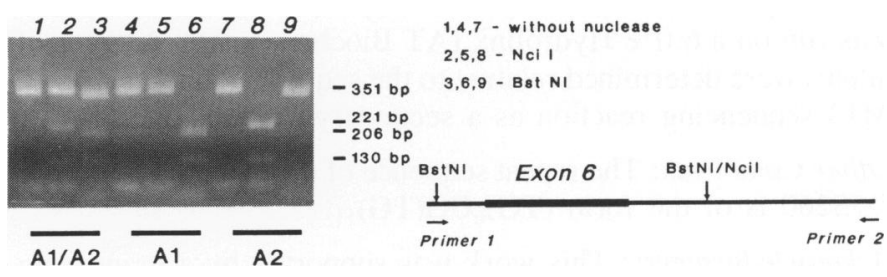

